\title{
Upper Miocene Ostracods of the Turiec Basin (Slovakia) - sub- family Cyclocypridinae
}

\author{
R. Pipík ${ }^{1 *}$, A.M. Bodergat ${ }^{2}$ \\ 1. Geological Institute, Slovak Academy of Sciences, Severná 5, SK-974 01 Banská Bystrica, Slovakia. \\ 2. Université Claude Bernard Lyon I, UFR Sciences de la Terre, bat. 402, 27-73 Bd. 11 Novembre, F-69622 Villeurbanne Cedex, France.
}

\begin{abstract}
Six species of the sub-family Cyclocypridinae were found in the Upper Miocene of the Turiec Basin, 4 of which are new Cypria isosceles, C. lenticulata, C. polyphema, C. bodergatiae. The differences in arrangement of the zone of the fusion on ventral margin were used to distinguish the species. The genus Cypria is represented in whole area of the Turiec Basin but the species are restricted to the ecologically well determined biotopes. Valve shape is compared with ecological stability of the paleobiotopes.
\end{abstract}

Keywords : Ostracoda, Miocene, Taxonomy, Paratethys, Slovakia.

\section{Introduction}

The recent Cyclocypridinae inhabit the freshwater environment ; their mode of reproduction is bisexual. The morphology of their valves is rather variable and depends on the environmental parameters (Sywula 1974, Tétard 1975, Petkovski 1976, Meisch 2000). They are known in the Lower and Middle Miocene freshwater deposits of Germany (Malz \& Moayedpour 1973, Janz 1997, Witt 2000). Many species of Cyclocypridinae, mainly of the genus Cypria, are found in the Central Paratethys, since the Pannonian (Tortonian) (Jiricek 1985). In the Miocene deposits of this area, Cypria is associated with the brackish species Cyprideis, Hemicytheria, Loxoconcha - and with the endemic Candona species sensu Krstic (1972). The outer margin of the Cypria valves ranges between circular, elliptic, triangular in shape and trapezoidal in shape with a concave dorsal margin (Krstić 1975, Pipík 1996).

The Turiec Basin corresponds to a Middle and Upper asymmetric intramountain depression located at the outer margin of the Central Paratethys (Fig. 1). It provides

\footnotetext{
*Corresponding author: E-mail : pipik@savbb.sk
}

an important lacustrine ostracods fauna of which six species belong to the Cyclocypridinae (Pipík 2001).

\section{Systematic description}

Abbreviations : RV - right valve, LV - left valve, C carapace, o - female valve, $\mathrm{O}^{\top}$ - male valve, AM - anterior margin, ADM - antero-dorsal margin, DM - dorsal margin, PDM - postero-dorsal margin, PM - posterior margin, PVM - postero-ventral margin, VM - ventral margin, AVM - antero-ventral margin, OM - outer margin, IM - inner margin, $\mathrm{H}_{\max }$ - maximum height, $\mathrm{E}_{\max }$ - maximum width, $\mathrm{A}$ - adult, $\mathrm{n}$ - quantity of measured individuals, 1 - length of the valve in $\mathrm{mm}, \mathrm{h}$ height of the valve in mm, $\varphi$ - average, h/l - height / length ratio.

The figured individuals are deposited in the Slovak National Museum in Bratislava (Slovakia) under the numbers mentioned in the text.

Class Ostracoda Latreille 1806

Order Podocopida Sars 1866

Suborder Podocopina Sars 1866

Family Candonidae Kaufmann 1900

Subfamily Cyclocypridinae Kaufmann 1900

Genus Cyclocypris Brady \& Norman 1889

Article available at http://www.limnology-journal.org or http://dx.doi.org/10.1051/limn/2003028 


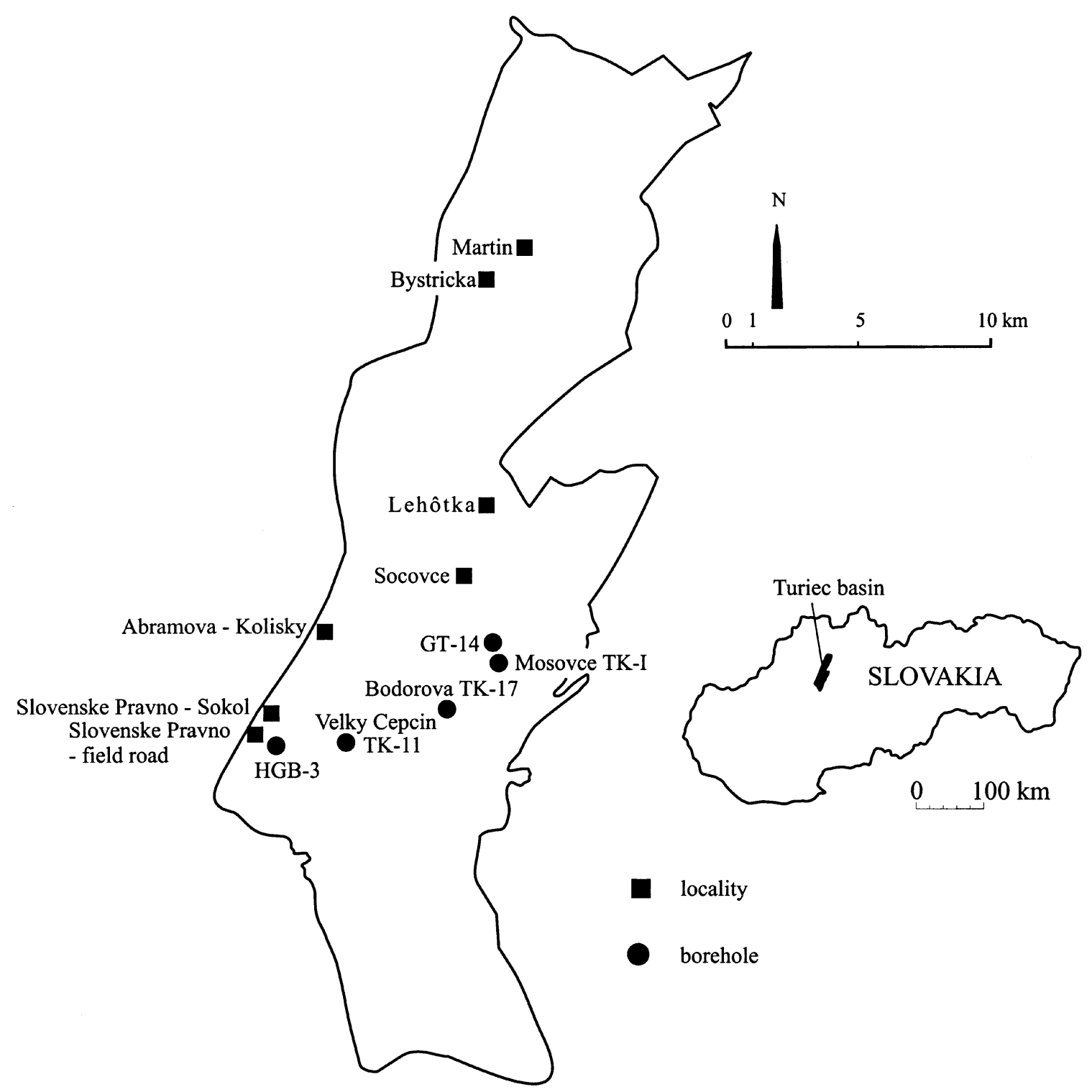

Fig. 1. Distribution of the genus Cypria in the Turiec Basin and its geographic location in Slovakia.

Cyclocypris laevis (O.F. Müller 1776)

Plate 1, Fig. 1

Cyclocypris laevis, Absolon, 1973, p. 66, Plate 3, Fig. 6.

Cyclocypris laevis, Diebel \& Pietrzeniuk, 1975, p. 1212, Plate VI, Figs. 7- 8.

? Cyclocypris laevis, Sokac, 1978, p. 32, Plate XVIII, Figs. 8-9.
Cyclocypris laevis, Diebel \& Pietrzeniuk, 1978, Plate 26, Figs. 1-2.

Cyclocypris laevis, Diebel \& Pietrzeniuk, 1984, p. 303-304, Plate V, Figs. 1-4.

Cyclocypris laevis, Fuhrman \& Pietrzeniuk, 1990, p. 191, Plate 6, Figs. 9-10.

Cyclocypris laevis, Pietrzeniuk, 1991, Plate 4, Figs. 
Table 1. Dimensions of Cyclocypris laevis (O.F. Müller), Zemné (Collection of Vladimír Pokorný (Prague)).

\begin{tabular}{cccccc}
\hline & & n & l & h & h/1 \\
\hline A & RV & 1 & 0.492 & 0.337 & 0.685 \\
\hline
\end{tabular}

Material and dimensions : 1 right valve.

Remarks : Cyclocypris cf. laevis (O.F. Müller 1776) of Diebel \& Pietrzeniuk (1977) from the Pleistocene travertine near Weimar (Germany) is more robust. Its $\mathrm{VM}$ is convex, PDM more curved and AM higher. $C y$ clocypris taubachensis Diebel \& Pietrzeniuk 1984 from the Late Pleistocene of the Germany is also more robust and more triangular at DM which is straight before and behind point of inflexion with $\mathrm{H}_{\max }$ located in the first half of the valve (Diebel \& Pietrzeniuk 1984). The recent individuals of Cyclocypris laevis figured by Sywula (1974) and Meisch (2000) are more rounded at DM. Our individual with low AM, triangular DM, PM regularly rounded and with VM slightly concave in middle of the length corresponds more to the individuals from Germany illustrated by Diebel \& Pietrzeniuk (1978, 1984).

Geographic and stratigraphic distribution : recent species from the Holarctic region are found in the Pleistocene and Holocene as well in the Pannonian deposits (Upper Miocene) of Slovakia. In the Collection of V. Pokorný, it was associated with Euxinocythere lactea Pipík \& Bodergat; the latest is known from the Upper Miocene of the Turiec Basin (Pipík \& Bodergat in press).

Ecology : a species very tolerant of variable ecological conditions, but it prefers permanent and temporary pools with vegetation; observed in the springs and lakes from littoral to the deepest zone. It tolerates a low salinity up to $8 \%$; thermoeuryplastic.

Regional distribution : Zemné (from Collection of Vladimír Pokorný (Prague)).

Literature : Van Morkhoven (1962), Devoto (1965), Rybecký (1986), Rühle (1994), Meisch (2000), Pipík (2000).

\section{Genus Cypria Zenker, 1854}

The significant differences between Cypria from the Turiec Basin are observed in the zone of fusion at the ventral margin (Fig. 2). These differences serve to distinguish species with similar valve morphology, such as Cypria servica Krstic 1975 and C. bodergatiae n.sp. and at the same time bring together valves of different outline such as Cypria polyphema (Plate 2, Fig. 1-7). The details of the zone of the fusion are described below.

\section{Cypria servica Krstic 1975}

Plate 1, Figs. 2-7 ; Plate 2, Fig. 15 ; Text-fig. 2a Cypria servica, Krstić, 1975, p. 198, Plate I, Figs. 12-13.

The original description being insufficient, we give a description on the basis of the material from the borehole HGB-3 (co-ordinates : 48 $51^{\prime} \mathrm{N}$ and $18^{\circ} 46^{\prime} \mathrm{E}$ ).
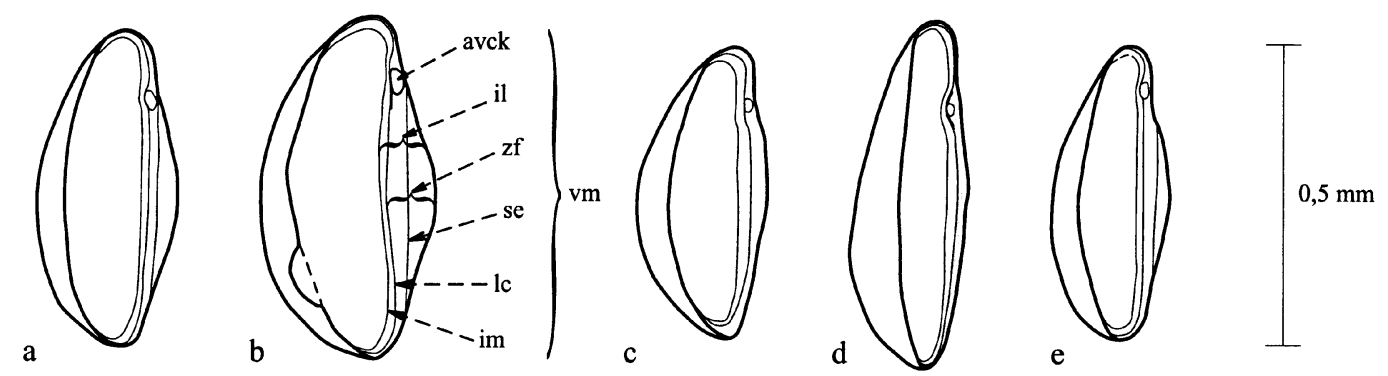

Fig. 2. Zone of the fusion on the ventral margin in dorsal view ; a) Cypria servica Krstić, b) C. isosceles n.sp., c) C. lenticulata n.sp., d) C. polyphema n.sp., e) C. bodergatiae n.sp. ; avck - antero-ventral contact-knob ; il - internal lamella ; zf - zone of fusion ; se - selvage ; lc line of concrescence ; im - inner margin ; vm - ventral margin. 
Table 2. Dimensions of Cypria servica Krstić, borehole HGB-3, $54.2 \mathrm{~m}$ and $55.5 \mathrm{~m}$.

\begin{tabular}{llllll}
\hline & & $\mathrm{n}$ & $\mathrm{l}$ & $\mathrm{h}$ & $\mathrm{h} / 1$ \\
\hline $\mathrm{A}$ & $\mathrm{LV}$ & 4 & $0.546-0.557$ & $0.431-0.451$ & $0.786-0.821$ \\
& $\mathrm{RV}$ & 4 & $0.529-0.551$ & $0.394-0.42$ & $0.744-0.772$ \\
\hline
\end{tabular}

Originally a diagnosis was not given, only a description of the valves. Accordingly from observations of the Turiec Basin material we can propose the following emended diagnosis.

Emended diagnosis : sub-trapezoidal species ; the LV strongly overlaps the RV on the VM ; LV with broad zone of the fusion on the VM behind the anteroventral contact knob.

Description :

$\mathrm{LV}$ - in lateral view AM low and regularly rounded passing into to the very long and slightly rounded ADM ; DM short and slightly rounded ; PM oblique, abrupt and almost straight passing into the regularly rounded PVM ; VM slightly concave or almost straight ; valve sub-trapezoidal in shape ; in dorsal view VM enlarged just behind the antero-ventral contact-knob ; $\mathrm{H}_{\max }$ situated at mid-length, $\mathrm{E}_{\max }$ behind the muscle scars.

RV - in lateral view AM high and regularly rounded, ADM long, almost straight, DM short, straight or rounded and sloping towards anterior, cardinal angles rounded ; PM oblique, abrupt and almost straight passing into the regularly rounded PVM ; VM slightly concave at the mid-length ; valve high, flattened and sub-trapezoidal in shape $; \mathrm{H}_{\max }$ situated at posterior, $\mathrm{E}_{\max }$ at centre.

Sexual dimorphism : not observed.

Overlap: not observed in dorsal view ; LV strongly overlaps the RV at the ventral side.

Muscle scars : Cypria arrangement.

Hinge : adont.

Ornamentation : smooth.

Normal pore canals : simple, regularly distributed over the surface..

Marginal zone (Fig. 2a) : zone of the fusion narrow at both ends, wide at VM of the LV and narrow on the $\mathrm{RV}$; inner lamella very narrow in anterior and posterior and large at VM; vestibulum narrow; line of concrescence and IM parallel to OM at anterior and posterior ; it is straight at VM ; selvage at VM of the LV ; marginal pore canals short, simple and well developed also at VM.

Material and dimensions : about 30 adult valves.

Plate 1. Fig. 1. = Cyclocypris laevis (O.F. Müller, 1776). 1 RV, l = 0,492 mm, h=0,337 mm ; No. RP9-40, Zemné, Pokorný’s collection ; external lateral view. Figs 2-7 = Cypria servica Krstić, 1975. $2 \mathrm{LV}, 1=0.549 \mathrm{~mm}, \mathrm{~h}=0.451 \mathrm{~mm}$; No. RP15-4, borehole HGB-3, 55.5 m ; internal lateral view. $3 \mathrm{RV}, 1=0.529 \mathrm{~mm}, \mathrm{~h}=0.394 \mathrm{~mm}$; No. RP15-1, borehole HGB-3, $54.2 \mathrm{~m}$; internal lateral view. $4 \mathrm{RV}, 1=0.551 \mathrm{~mm}, \mathrm{~h}=0.42$ $\mathrm{mm}$; No. RP15-2, borehole HGB-3, $55.5 \mathrm{~m}$; external lateral view. $5 \mathrm{LV}, 1=0.557 \mathrm{~mm}, \mathrm{~h}=0.439 \mathrm{~mm}$; No. RP15-5, borehole HGB-3, 55.5 $\mathrm{m}$; external lateral view. $6 \mathrm{LV}, 1=0.546 \mathrm{~mm}, \mathrm{~h}=0.435 \mathrm{~mm}, \mathrm{e}=0,157 \mathrm{~mm}$; No. RP15-6, borehole HGB-3, $54.2 \mathrm{~m}$; dorsal view. $7 \mathrm{RV}, 1=$ $0.543 \mathrm{~mm}, \mathrm{~h}=0.412 \mathrm{~mm}, \mathrm{e}=0.118 \mathrm{~mm}$; No. RP15-3, borehole HGB-3, $55.5 \mathrm{~m}$; dorsal view. Figs 8-14 = Cypria isosceles n.sp. 8 RV, holotype, $1=0.549 \mathrm{~mm}, \mathrm{~h}=0.422 \mathrm{~mm}$; No. RP15-7, borehole HGB-3, $54.6 \mathrm{~m}$; internal lateral view. $9 \mathrm{LV}, \mathrm{paratype}, 1=0.569 \mathrm{~mm}, \mathrm{~h}=0.471$ $\mathrm{mm}$; No. RP15-11, borehole HGB-3, $104.8 \mathrm{~m}$; internal lateral view. $10 \mathrm{RV}$, paratype, $1=0.589 \mathrm{~mm}, \mathrm{~h}=0.471 \mathrm{~mm}$; No. RP15-9, borehole GT-14, 177.5-177.6 m ; external lateral view. $11 \mathrm{RV}$, paratype, $1=0.571 \mathrm{~mm}, \mathrm{~h}=0.434 \mathrm{~mm}$; No. RP15-8, borehole HGB-3, $104.8 \mathrm{~m}$; external lateral view. $12 \mathrm{LV}$, paratype, $1=0.589 \mathrm{~mm}, \mathrm{~h}=0.465 \mathrm{~mm}$; No. RP15-12, borehole GT-14, 177.5-177.6 m ; external lateral view. $13 \mathrm{LV}$, paratype, $1=0.569 \mathrm{~mm}, \mathrm{~h}=0.471 \mathrm{~mm}, \mathrm{e}=0.18 \mathrm{~mm}$; No. RP15-13, borehole HGB-3, 207.3-207.5 m ; dorsal view. $14 \mathrm{RV}$, paratype, $1=0.569$ $\mathrm{mm}, \mathrm{h}=0.434 \mathrm{~mm}, \mathrm{e}=0.137 \mathrm{~mm}$; No. RP15-10, borehole HGB-3, 207.3-207.5 m ; dorsal view. Figs 15-24=Cypria lenticulata $\mathrm{n} . \mathrm{sp} .15 \mathrm{LV}$, holotype, $1=0.49 \mathrm{~mm}, \mathrm{~h}=0.347 \mathrm{~mm}$; No. RP4-43, Slovenské Pravno - field road PC4 ; internal lateral view. $16 \mathrm{RV}$, paratype, $1=0.473 \mathrm{~mm}$, $\mathrm{h}=0.316 \mathrm{~mm}$; No. RP4-46, Slovenské Pravno - field road PC4 ; internal lateral view. 17 RVO, paratype, $1=0.475 \mathrm{~mm}, \mathrm{~h}=0.333 \mathrm{~mm} ; \mathrm{No}$. RP4-45, Slovenské Pravno - field road PC4; external lateral view. 18 LVŸo, paratype, $1=0.486$ mm, h = 0.347 mm ; No. RP4-44, Slovenské Pravno - field road PC4 ; external lateral view. 19 LVQ, paratype, $1=0.484 \mathrm{~mm}, \mathrm{~h}=0.353 \mathrm{~mm}$; No. RP4-42, Slovenské Pravno - field road PC4 ; external lateral view. 20 LVơ', paratype, $1=0.524 \mathrm{~mm}, \mathrm{~h}=0.373 \mathrm{~mm}$; No. RP4-48, Slovenské Pravno - field road PC4 ; internal lateral view. $21 \mathrm{RVO}$, paratype, $1=0.506 \mathrm{~mm}, \mathrm{~h}=0.359 \mathrm{~mm}$; No. RP4-49, Slovenské Pravno - field road PC4 ; internal lateral view. 22 RVơ', paratype, $1=0.525 \mathrm{~mm}, \mathrm{~h}=0.369 \mathrm{~mm}$; No. RP4-56, Slovenské Pravno - field road PC4 ; external lateral view. $23 \mathrm{LV} \sigma^{\prime}$, paratype, $1=0.516$ mm, $\mathrm{h}=0.375 \mathrm{~mm}$; No. RP4-52, Slovenské Pravno - field road PC4; external lateral view. 24 CQ, paratype, $1=0.527 \mathrm{~mm}, \mathrm{~h}=0.373 \mathrm{~mm}, \mathrm{e}=0.236$ mm ; No. RP4-53, Slovenské Pravno - field road PC4 ; dorsal view. 


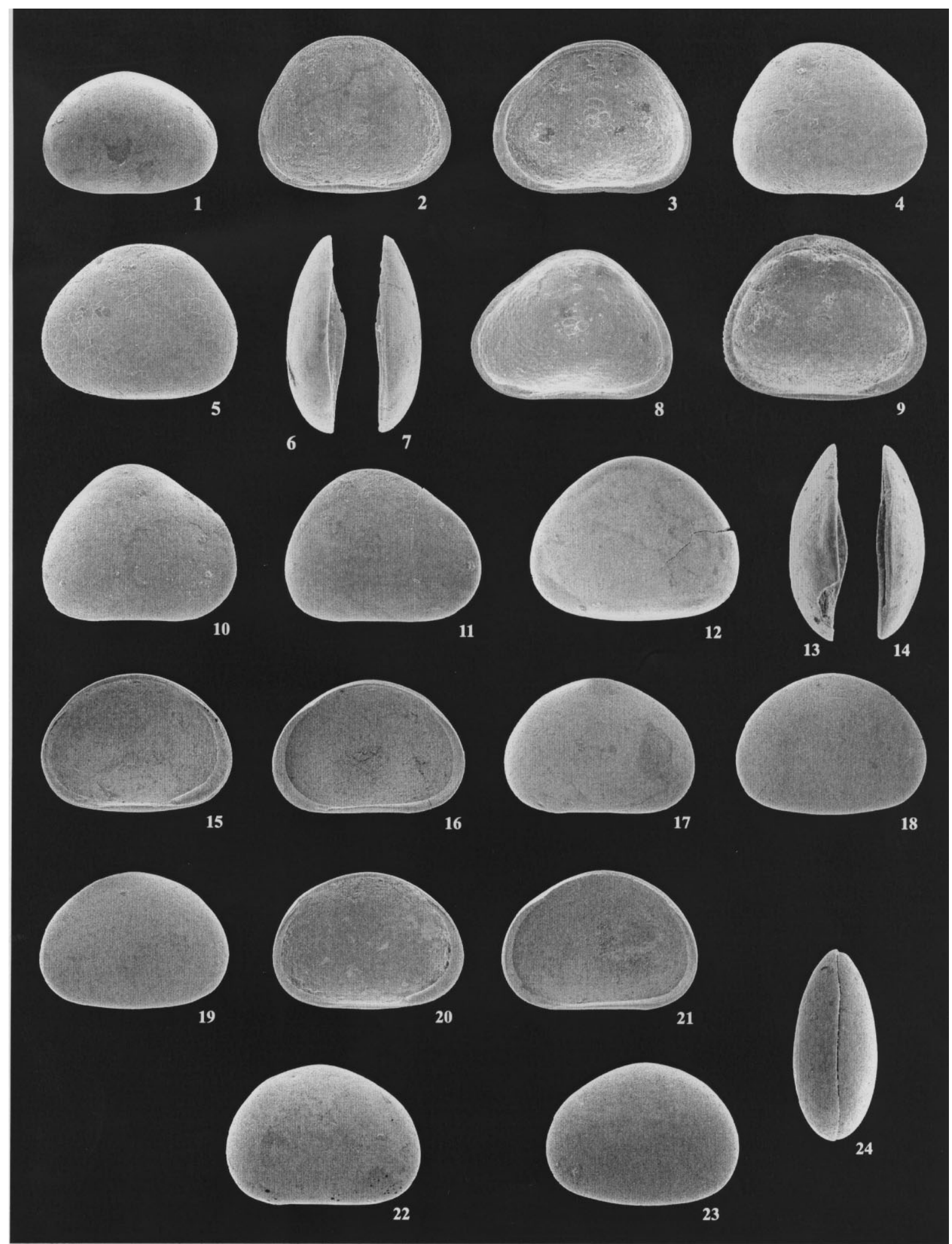


Remarks : The holotype and the paratype described by Krstic $(1975)$ are larger $(1=0.61 \mathrm{~mm} ; \mathrm{h}=0.51$ $\mathrm{mm})$. Their $\mathrm{h} / \mathrm{l}$ ratio (0.836, resp. 0.817 ) is also higher than that of the individuals from the Turiec Basin. The $\mathrm{LV}$ is more rounded at VM and less rounded at its DM. The RV is not so concave.

Cypria dorsoconcava Krstic 1975 from the brackish Pannonian deposits of the Serbia is larger with concave DM. $\mathrm{H}_{\text {max }}$ of the RV is located at the posterior (Krstic 1975). C. tocorjescui Hanganu 1962 from the Upper Miocene of the Central Paratethys has the DM longer, it's AM and PM are more abrupt (Sokac 1972). C. isosceles n.sp. is triangular with line of concrescence curved at the VM. Its point of inflection is rounded.

Geographic and stratigraphic distribution : fossil species are known from the Pannonian (Upper Miocene) of the Yugoslavia (Central Paratethys) (Krstic 1975).
Regional distribution : borehole GT-14, borehole HGB-3.

Cypria isosceles n.sp.

Plate 1, Figs. 8-14 ; Plate 2, Fig. 16 ; Text-fig. 2b

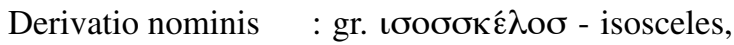
after the triangular shape of the valves.

Holotype : RV, No. RP15-7 ; Plate 1, Fig. 8 ; Plate 2, Fig. 16.

Paratypes: Plate 1, Fig. 9-14 (No. RP15-8, No. RP15-9, No. RP15-10, No. RP15-11, No. RP15-12, No. RP15-13).

Locus typicus: borehole HGB-3, sample $104.8 \mathrm{~m}$, Turiec Basin (Slovakia) ; co-ordinates - 48 $51^{\prime} \mathrm{N}$ and $18^{\circ} 46^{\prime} \mathrm{E}$.

Stratum typicum : Upper Miocene.

Table 3. Dimensions of Cypria isosceles n.sp., borehole HGB-3, $104.8 \mathrm{~m}$.

\begin{tabular}{clcccc}
\hline & & $\mathrm{n}$ & $\mathrm{l}$ & $\mathrm{h}$ & $\mathrm{h} / 1$ \\
\hline A & RV, holotype & 0.549 & 0.422 & 0.769 \\
& LV & 1 & 0.569 & 0.471 & 0.828 \\
& RV & 3 & $0.531-0.571$ & $0,373-0.434$ & $0.701-0.786$ \\
atypical & LV & 3 & $0.524-0.535$ & $0.404-0.414$ & $0.769-0.781$ \\
individuals & RV & 2 & $0.531-0.551$ & $0.373-0.396$ & $0.701-0.719$ \\
A-1 & LV & 3 & $0.47-0.49$ & $0.355-0.373$ & $0.728-0.779$ \\
& RV & 2 & $0.469-0.471$ & $0.349-0.353$ & $0.745-0.75$ \\
A-2 & LV & 1 & 0.412 & 0.3 & 0.729 \\
& RV & 2 & $0.396-0.435$ & $0.302-0.316$ & $0.725-0.762$ \\
A-3 & RV & 1 & 0.353 & 0.261 & 0.739 \\
\hline
\end{tabular}

Plate 2. Figs 1-7 = Cypria polyphema n.sp. $1 \mathrm{LV}$, holotype, $1=0.551 \mathrm{~mm}, \mathrm{~h}=0.396 \mathrm{~mm}$; No. RP3-30, Slovenské Pravno - field road PC4 ; external lateral view. $2 \mathrm{LV}$, paratype, $\mathrm{l}=0.582 \mathrm{~mm}, \mathrm{~h}=0.431 \mathrm{~mm}$; No. RP3-31, Martin MT-33 ; external lateral view. 3 RV, paratype, $1=0.549$ $\mathrm{mm}, \mathrm{h}=0.375 \mathrm{~mm}$; No. RP3-36, Slovenské Pravno - field road PC4 ; external lateral view. $4 \mathrm{RV}$, paratype, $1=0.55 \mathrm{~mm}, \mathrm{~h}=0.376 \mathrm{~mm}$; No. RP3-37, Slovenské Pravno - field road PC4 ; internal lateral view. 5 LV, paratype, $1=0.612 \mathrm{~mm}, \mathrm{~h}=0.451 \mathrm{~mm}$; No. RP3-35, Martin MT-33 ; external lateral view. $6 \mathrm{RV}$, paratype, $1=0.567 \mathrm{~mm}, \mathrm{~h}=0.414 \mathrm{~mm}$; No. RP3-32, Slovenské Pravno - field road PC4 ; external lateral view. 7 $\mathrm{RV}$, paratype, $1=0.578 \mathrm{~mm}, \mathrm{~h}=0.41 \mathrm{~mm}$; No. RP3-33, Slovenské Pravno - field road PC4 ; internal lateral view. Figs 8-14 = Cypria bodergatiae Pipík n.sp. 8,14 RVO, holotype, $1=0.512 \mathrm{~mm}, \mathrm{~h}=0.38 \mathrm{~mm}, \mathrm{e}=0.12 \mathrm{~mm}$; No. RP14-22, borehole HGB-3, $104.8 \mathrm{~m} ; 8-$ internal lateral view, 14 - dorsal view. 9, 13 LVO, paratype, $1=0.492 \mathrm{~mm}, \mathrm{~h}=0.392 \mathrm{~mm}, \mathrm{e}=0.122 \mathrm{~mm}$; No. RP14-25, borehole HGB-3, $104.8 \mathrm{~m} ; 9$ - internal lateral view, 13 - dorsal view. $10 \mathrm{RVO}$, paratype, $1=0.5 \mathrm{~mm}, \mathrm{~h}=0.375 \mathrm{~mm}$; No. RP14-23, borehole HGB-3, $104.8 \mathrm{~m}$; external lateral view. $11 \mathrm{LV}$, paratype, $1=0.496 \mathrm{~mm}, \mathrm{~h}=0.388 \mathrm{~mm}$; No. RP14-26, borehole HGB-3, $104.8 \mathrm{~m}$; external lateral view. 12 RVo', paratype, 1 $=0.514 \mathrm{~mm}, \mathrm{~h}=0.394 \mathrm{~mm} ;$ No. RP14-24, borehole HGB-3, $104.8 \mathrm{~m} ;$ internal lateral view. Fig. 15 Cypria servica Krstić, $1975 ; \mathrm{RV}, 1=0.529$ $\mathrm{mm}, \mathrm{h}=0.394 \mathrm{~mm}$; No. RP15-1, borehole HGB-3, $54.2 \mathrm{~m}$; external lateral view. Fig. 16. Cypria isosceles n.sp. ; RV, holotype, $1=0.549$ mm, $\mathrm{h}=0.422 \mathrm{~mm}$; No. RP15-7, borehole HGB-3, $54.6 \mathrm{~m}$; external lateral view. Fig. 17. Cypria lenticulata n.sp. ; LVO, holotype, $1=0.49$ mm, $\mathrm{h}=0.347 \mathrm{~mm}$; No. RP4-43, Slovenské Pravno - field road PC4 ; external lateral view. Fig. 18. Cypria polyphema n.sp. ; LV, holotype, 1 = $0.551 \mathrm{~mm}, \mathrm{~h}=0.396 \mathrm{~mm}$; No. RP3-30, Slovenské Pravno - field road PC4 ; external lateral view. Fig. 19. Cypria bodergatiae Pipík n.sp. ; RVO, holotype, $1=0.512 \mathrm{~mm}, \mathrm{~h}=0.38 \mathrm{~mm}$; No. RP14-22, borehole HGB-3, 104,8 m ; external lateral view. 

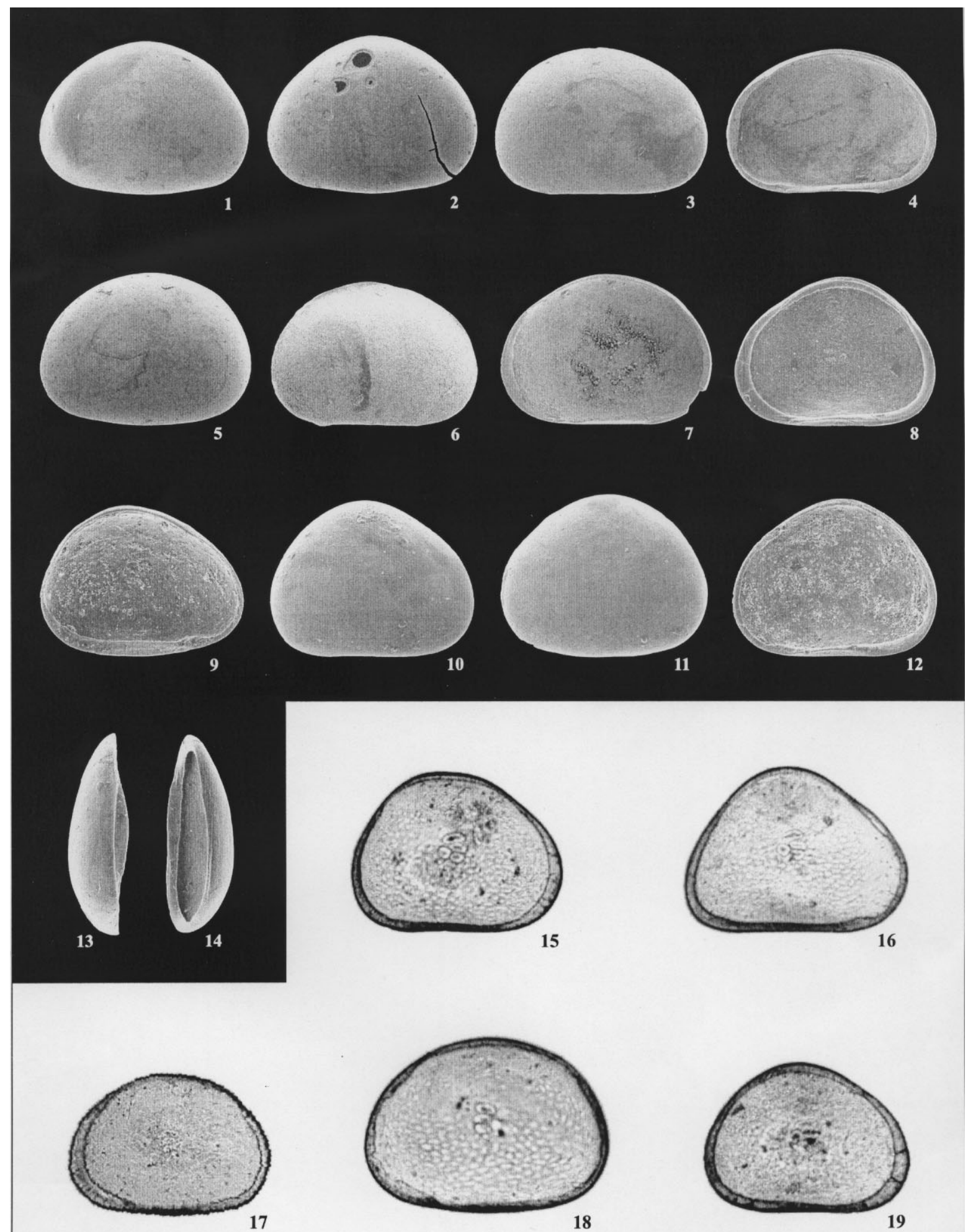
Diagnosis : A species with triangular valve in shape ; in dorsal view VM enlarged strongly on the LV and weakly on the RV; zone of the fusion very enlarged at $\mathrm{VM}$ of the LV ; course of the line of concrescence at ventral opposite to course of the VM (Fig. 2b).

Description :

LV - in lateral view AM low and regularly rounded, DM triangular, PM oblique, abrupt and slightly rounded, PVM rounded, VM largely rounded ; valve triangular in shape ; in dorsal view VM strongly enlarged ; $\mathrm{H}_{\text {max }}$ situated at the centre, $\mathrm{E}_{\max }$ behind the muscle scars.

RV - in lateral view AM high and regularly rounded, DM triangular and curved at the point of inflexion, PM straight, PVM rounded, VM largely concave ; valve flattened, triangular in shape ; in dorsal view VM slightly enlarged ; $\mathrm{H}_{\max }$ situated behind mid-length, $\mathrm{E}_{\text {max }}$ behind muscle scars.

Atypical individuals : outline identical with normal individuals ; their zone of the fusion is very narrow at VM.

Sexual dimorphism : not observed.

Overlap : in ventral view LV strongly overlaps the RV.

Muscle scars : Cypria arrangement.

Hinge : adont.

Ornamentation : surface smooth or covered by weak punctuation.

Normal pore canals : simple, regularly distributed over the surface.

Marginal zone (Fig. 2b) : zone of the fusion narrow at anterior and posterior, very wide at $\mathrm{VM}$ of the $\mathrm{LV}$; it is narrow on the RV ; inner lamella narrow anteriorly and somewhat narrower posteriorly, vestibulum narrow ; line of concrescence and inner margin parallel at anterior and posterior ; course of the line of concrescence at ventral opposite to course of the VM ; selvage at VM of the LV ; marginal pore canals short, simple and well developed also at VM.
Material and dimensions : about 30 adult valves and a few tens of juveniles.

Remarks : It is necessary to emphasise the very broad zone of fusion on the LV of C. isosceles n.sp. which distinguishes it from the other species of the Turiec Basin. Cypria servica Krstic from the Turiec Basin has a subtrapezoidal shape with straight DM. Its line of concrescence is always straight at the VM. C. bodergatiae n.sp. is smaller, subcircular to subtriangular. The triangular forms of Cypria are well-known from the Upper Miocene of SE Pannonian Basin but their morphological characteristics well differentiate them from C. isosceles n.sp. C. triebeli Krstic 1975 has straight DM, C. siboviki Krstic 1975 has rounded DM and anterior and posterior of the same height (Krstic 1975). With an equilateral triangle shape, outline of Advenocypris alpherovi Schneider 1956 from the Sarmatian deposits of the former USSR presents an extremely symmetrical form (Mandelstam \& Schneider 1963). $\mathrm{H}_{\max }$ of C. karamani Petkovski 1976 and $C$. sketi Petkovski 1976, both the recent species from the former Yugoslavia, is situated at the mid-length; their IM is almost parallel with the outline at the VM. In dorsal view, C. sketi is wider posteriorly (Petkovski 1976).

Regional distribution : Abramová - Kolísky, Slovenské Pravno - Sokol, Socovce, borehole GT-14, borehole HGB-3, borehole Mosovce TK-I, borehole Bodorová TK-17.

\section{Cypria lenticulata $\mathrm{n} . \mathrm{sp}$.}

Plate 1, Figs. 15-24 ; Plate 2, Fig. 17 ; Text-fig. 2c

Derivatio nominis: lat. lenticularis - having the shape of the lens, after the lentil-like outline of the valves.

Holotype: LVO, No. RP4-43 ; Plate 1, Fig. 15 ; Plate 2, Fig. 17.

Paratypes: Plate 1, Fig. 16-24 (No. RP4-42, No. RP4-44, No. RP4-45, No. RP4-46,

Table 4. Dimensions of Cypria lenticulata n.sp., Slovenské Pravno - field road PC 4.

\begin{tabular}{|c|c|c|c|c|c|c|c|c|}
\hline & & $\mathbf{n}$ & 1 & $\varphi$ & h & $\varphi$ & $\mathrm{h} / \mathrm{l}$ & $\varphi$ \\
\hline \multirow[t]{5}{*}{ A } & LVO, & lotype & 0.49 & - & 0.347 & - & 0.708 & - \\
\hline & $\mathrm{LV}^{\hat{\alpha}}$ & 26 & $0.506-0.535$ & 0.518 & $0.359-0.388$ & 0.372 & $0.696-0.739$ & 0.718 \\
\hline & $\mathrm{RV}^{\hat{\partial}}$ & 42 & $0.48-0.529$ & 0.508 & $0.337-0.375$ & 0.354 & $0.676-0.726$ & 0.697 \\
\hline & LV우 & 33 & $0.473-0.512$ & 0.49 & $0.333-0.361$ & 0.35 & $0.677-0.732$ & 0.713 \\
\hline & RV우 & 42 & $0.467-0.512$ & 0.487 & $0.317-0.353$ & 0.336 & $0.665-0.709$ & 0.69 \\
\hline
\end{tabular}


No. RP4-48, No. RP4-49, No. RP4-52, No. RP4-53, No. RP4-56).

Locus typicus: Slovenské Pravno - field road, sample PC 4, Turiec Basin (Slovakia); co-ordinates $48^{\circ} 53^{\prime} \mathrm{N}$ and $18^{\circ} 46^{\prime} \mathrm{E}$.

Stratum typicum: Upper Miocene.

Diagnosis: small subcircular species ; in dorsal view contour inflated and symmetrical on the LV and asymmetrical on the RV ; course of the overlap sinusoidal at DM, PVM of the RV carrying a small expansion.

Description :

LVO - in lateral view AM regularly rounded, DM rounded, PM rounded, VM slightly convex ; in dorsal view contour inflated and symmetric ; valve subcircular in shape $; \mathrm{H}_{\max }$ situated at mid-length, $\mathrm{E}_{\max }$ behind muscle scars.

RVQ - in lateral view AM high and rounded, DM rounded or slightly triangular, PM rounded, VM concave ; in dorsal view contour slightly inflated and symmetrical ; valve subcircular in shape ; PVM carrying a small expansion ; HO at centre, EO behind muscle scars.

LVơ' - in lateral view AM rounded, lower than PM ; ADM almost straight, DM rounded, $\mathrm{PM}$ high and rounded, VM slightly convex ; in dorsal view contour slightly inflated and asymmetrical ; valve subcircular in shape $; \mathrm{H}_{\max }$ situated at mid-length, $\mathrm{E}_{\max }$ at posterior.

RVo' - in lateral view AM rounded and lower than PM, DM slightly triangular with rounded point of inflection, PDM angled, PM rounded, VM slightly concave ; in dorsal view contour slightly inflated and symmetrical ; valve subcircular in shape ; PVM carrying a small expansion; $\mathrm{H}_{\max }$ situated at centre, $\mathrm{E}_{\max }$ at posterior.

Sexual dimorphism : the morphological differences between the sexes are weak ; in the lateral view the males are higher and angled at PDM while the females are broader

Overlap : irregular, sinusoidal at DM, LV overlaps the RV at both ends.

Muscle scars : Cypria arrangement.

Hinge : adont.

Ornamentation : smooth.

Normal pore canals : simple, regularly distributed over the surface.

Marginal zone (Fig. 2c) : zone of the fusion narrow at anterior and posterior, twice as large at $\mathrm{VM}$; inner lamella narrow ; vestibulum narrow ; line of concrescence and IM parallel to OM except of VM ; they are firstly slightly curved and then straight ; marginal pore canals short, fine, straight, more dense at AVM.

Material and dimensions : about 300 adult valves.

Remarks : The outline of Cypria lenticulata n.sp. in external lateral view is rather similar to Cyclocypris. The presence of only one antero-ventral contact-knob differentiates it from the Cyclocypris species which have two ventral contact knobs (Morkhoven 1962). The outline of Cypria lenticulata n.sp. seems morphologically very similar to the recent Middle European species especially to Cypria ophtalmica (Jurine 1820) whose morphology is quite variable. C. ophtalmica is larger $(0.54-0.70 \mathrm{~mm})$; its DM is largely and regularly rounded ; the VM is slightly concave (Meisch 2000). Cypria reptans 1928 Bronshtein has a broader inner lamella with more concave VM. Cypria exsculpta (Fischer 1855) has longitudinal striation on the valves. Cypria subsalsa Redeke 1936 is more elliptical ; its DM is largely rounded. Cypria sywulae Meisch 2000 is broader with more symmetrical and almost circular outline. The line of overlap in dorsal view of all the mentioned species is straight or slightly curved before mid-length (Sywula 1974, Meisch 2000). On the other hand, it is sinusoidal in C. lenticulata n.sp.

Regional distribution : Slovenské Pravno - field road. It is known also from the Martin locality although not from its actual profile.

$$
\text { Cypria polyphema n.sp. }
$$

Plate 2, Figs. 1-7, 18 ; Text-fig. 2d

Derivatio nominis: lat. Polyphemos - Polyphemus, son of Neptune in Greek mythology, cyclop ; according to eye shape of the outline.

Holotype: LV, No. RP3-30 ; Plate 2, Fig. 1, 18.

Paratypes: Plate 2, Fig. 2-7 (No. RP3-31, No. RP332, No. RP3-33, No. RP3-35, No. RP3-36, No. RP337).

Locus typicus: Martin, sample MT-33, Turiec Basin (Slovakia) ; co-ordinates $-49^{\circ} 04^{\prime} \mathrm{N}$ and $18^{\circ} 53^{\prime} \mathrm{E}$.

Stratum typicum: Upper Miocene.

Diagnose : subcircular and slightly inflated in shape ; $\mathrm{OM}$ of the LV exceeds outline at ventral side ; PVM of the RV carrying a small expansion ; zone of the fusion narrow at VM ; line of concrescence follows the changes of the VM.

Description :

LV adult - in lateral view AM and DM regularly rounded, PM rounded, VM straight or convex ; valve slightly inflated and subcircular in shape ; ventral area exceeds OM ; in dorsal view VM slightly inflated and 
Table 5. Dimensions of Cypria polyphema n.sp., Slovenské Pravno - field road PC 4 ;

* - LV from Slovenské Pravno - field road PC 1, PC 4 and Martin MT-33.94.

\begin{tabular}{ccccccccc}
\hline & & $\mathrm{n}$ & $\mathrm{l}$ & $\varphi$ & $\mathrm{h}$ & $\varphi$ & $\mathrm{h} / 1$ & $\varphi$ \\
\hline $\mathrm{A}$ & $\mathrm{LV}$, holotype & 0.551 & - & 0.396 & - & 0.719 & - \\
& $\mathrm{LV}$ & 5 & $0.551-0.612$ & 0.582 & $0.396-0.451$ & 0.428 & $0.719-0.742$ & 0.735 \\
& $\mathrm{RV}$ & 4 & $0.569-0.583$ & - & $0.395-0.414$ & - & $0.695-0.728$ & - \\
atypical & $\mathrm{LV}$ & 15 & $0.531-0.569$ & 0.549 & $0.375-0.398$ & 0.39 & $0.693-0.727$ & 0.71 \\
individuals & $\mathrm{RV}$ & 11 & $0.527-0.555$ & 0.544 & $0.353-0.386$ & 0.37 & $0.652-0.708$ & 0.681 \\
$\mathrm{~A}-1$ & $\mathrm{LV}$ & 25 & $0.453-0.524$ & 0.48 & $0.316-0.369$ & 0.333 & $0.675-0.713$ & 0.695 \\
& $\mathrm{RV}$ & 31 & $0.451-0.494$ & 0.474 & $0.298-0.343$ & 0.315 & $0.646-0.7$ & 0.664 \\
$\mathrm{~A}-2$ & $\mathrm{LV}$ & 4 & $0.404-0.422$ & - & $0.278-0.29$ & - & $0.676-0.689$ & - \\
& $\mathrm{RV}$ & 3 & $0.393-0.394$ & - & $0.257-0.267$ & - & $0.653-0.677$ & - \\
& & & & & & & & \\
\hline
\end{tabular}

symmetrical $; \mathrm{H}_{\max }$ situated slightly before mid-length of the valve, $\mathrm{E}_{\max }$ in central area.

RV adult - in lateral view rounded AM pass to straight ADM, DM rounded, PDM rounded to slightly rounded, PM rounded, VM straight ; valve slightly inflated and subcircular in shape ; PVM carrying a small expansion ; $\mathrm{H}_{\max }$ situated at middle of the length, $\mathrm{E}_{\max }$ in posterior area.

LV atypical - in lateral view AM rounded, DM rounded before a point of inflection, oblique and almost straight behind it, PDM slightly curved, PM rounded, VM convex, slightly inflated subcircular in shape ; in dorsal view outline enlarged and symmetrical ; $\mathrm{H}_{\text {max }}$ situated before mid-length, $\mathrm{E}_{\max }$ at centre.

RV atypical - in lateral view AM rounded, DM slightly triangular, PM rounded, VM concave ; slightly inflated subcircular in shape ; in dorsal view outline symmetrical and very slightly inflated ; PVM carrying a small expansion; $\mathrm{H}_{\max }$ situated at centre or before mid-length, $\mathrm{E}_{\max }$ at centre of the valve.

Sexual dimorphism : difficult to distinguish.

Overlap : LV overlaps RV.

Muscle scars : Cypria arrangement.

Hinge : adont.

Ornamentation : smooth.

Normal pore canals : simple, regularly distributed over the surface.

Marginal zone (Fig. 2d) : zone of the fusion narrow over all its length, inner lamella narrow, wider at VM ; vestibulum narrow; line of concrescence parallel to
OM over all its length ; it follows the line of OM ventrally ; IM parallel to OM at anterior and posterior ; it is slightly curved at area of antero-ventral contactknob then straight until the posterior end of the VM ; marginal pore canals simple, thin, short, fairly dense over all the length of AVM, very rare at ADM.

Material and dimensions : 17 adult valves, about 40 valves of atypical individuals and 90 juveniles valves.

Remarks : The line of overlap at DM of Cypria subsalsa is straight behind the mid-length. In internal view, the $\mathrm{LV}$ is concave at $\mathrm{VM}$ and its $\mathrm{h} / \mathrm{l}$ ratio is lower than that of $C$. polyphema n.sp. C. lenticulata n.sp. is smaller; its zone of fusion is broad at VM.

Cypria ophtalmica has straight or concave VM and more circular and wider postero-dorsal part. The inner lamella of Cypria reptans is broad (Sywula 1974, Meisch 2000).

The LV of Cypria obesa Sharpe 1897 from the Pleistocene of Illinois (USA) with $\mathrm{H}_{\text {max }}$ anteriorly is close to the atypical individuals of $C$. polyphema n.sp., but the adults of $C$. obesa are larger, more elongated and with slightly triangular DM (Staplin 1963).

Cypria polyphema n.sp. is larger and more circular than C. abbreviata (Reuss 1850) from the Pannonian of the Central Paratethys which has strongly calcified valves ; its zone of fusion is narrow at VM (Jiříček 1985, Pipík 1996).

Regional distribution : Lehôtka, Slovenské Pravno field road, Martin, Bystricka, borehole Vel'ký Čepčín TK-11. 


\section{Cypria bodergatiae Pipík n.sp.}

Plate 2, Fig. 8-14, 19 ; Text-fig. 2e

Derivation nominis : after Dr. Anne-Marie Bodergat, french ostracodologist.

Holotype: RV, No. RP14-22 ; Plate2, Fig. 8, 14, 19.

Paratypes: Plate2, Fig. 9-13 (No. RP14-23, No. RP14-24, No. RP14-25, No. RP14-26).

Locus typicus: borehole HGB-3, sample $104.8 \mathrm{~m}$, Turiec Basin (Slovakia) ; co-ordinates - $48^{\circ} 51^{\prime} \mathrm{N}$ and $18^{\circ} 46^{\prime} \mathrm{E}$.

Stratum typicum: Upper Miocene.

Diagnose: subtriangular to subelliptical small-sized species ; in dorsal view VM of the LV large, broad and symmetrical.

Description :

LVO - in lateral view AM low and rounded, DM at first straight then strongly curved, VM slightly concave ; subtriangular to subelliptical in shape ; in dorsal view VM symmetrically rounded; $\mathrm{H}_{\max }$ situated at the mid-length, $\mathrm{E}_{\max }$ right behind the muscle scars.

RVO - in lateral view AM regularly rounded and high, ADM oblique and straight or slightly concave, DM slightly triangular and curved at its point of inflexion, DM at first slightly curved and then strongly curved, VM slightly concave at the level of the muscle scars ; subtriangular to subcircular in shape ; in dorsal view VM very slightly enlarged or almost straight; $\mathrm{H}_{\text {max }}$ is situated behind the mid- length, $\mathrm{E}_{\max }$ in posterior area.

LVơ - not known.

RVo' - in lateral view AM regularly rounded, ADM straight, DM at first slightly rounded, abrupt and then strongly curved, VM slightly concave ; circular in shape ; in dorsal view VM very slightly enlarged or almost straight ; $\mathrm{H}_{\max }$ situated at mid-length, $\mathrm{E}_{\max }$ in posterior area.

Sexual dimorphism : the male is more enlarged at the PDM and more abrupt at its PM, the females are more triangular.
Overlap: not observed.

Muscle scars : Cypria arrangement.

Hinge: adont.

Ornamentation: smooth.

Normal pore canals: simple, regularly distributed over the surface.

Marginal zone (Fig. 2e) : zone of the fusion narrow, wide at VM of the LV ; inner lamella very narrow posteriorly, larger anteriorly ; vestibulum narrow ; line of concrescence and IM parallel to OM at anterior and posterior ; it is parallel to selvage at $\mathrm{VM}$ of the $\mathrm{LV}$; marginal pore canals short, straight, thin and denser at AVM than ADM ; a few marginal pore canals are also developed at VM.

Material and dimensions : 76 adult valves.

Remarks : Cypria isosceles n.sp. is triangular. Its juveniles are more flattened on the dorsal area and their $\mathrm{H}_{\max }$ is situated at the anterior. DM of C. servica is straight ; VM is assymetrical. Valves of C. polyphema are slimmer and subcircular ; its zone of the fusion is always thin at VM. Cypria exsculpta is plumper. DM of Cypria ophtalmica is bow-shaped as in C. helokrenica Kantorek \& Absolon 1975, recent species, in which the inner lamella is larger (Sywula 1974, Kantorek \& Absolon 1975, Meisch 2000). The left valve of $C$. dorsalta Malz \& Moayedpour 1973 from the Miocene of the Germany has DM longer, more rounded and symmetrical. Hmax of the right valve is situated more posteriorly ; its PM is more abrupt (Malz \& Moayedpour 1973). $\mathrm{H}_{\max }$ of C. karamani and C. sketi is situated at mid-length; their IM is almost parallel with OM. C. sketi is larger posteriorly in dorsal view ; its right valve is more triangular (Petkovski 1976).

Regional distribution : borehole HGB-3, Slovenské Pravno-Sokol.

Remarks on the morphology and the ecological distribution of the Cypria species

In Cypria known in Recent environments, the valves of both sexes are either identical (C. subsalsa, C. sywulae, C. karamani), or the females ones are a little

Table 6. Dimensions of Cypria bodergatiae n.sp., borehole HGB-3, 104.8 m.

\begin{tabular}{clccccccc}
\hline & & $\mathrm{n}$ & $\mathrm{l}$ & $\varphi$ & $\mathrm{h}$ & $\varphi$ & $\mathrm{h} / 1$ & $\varphi$ \\
\hline $\mathrm{A}$ & RV & holotype & 0.512 & - & 0.38 & - & 0.742 & - \\
& $\mathrm{RVO}$ & 1 & 0.514 & - & 0.394 & - & 0.767 & - \\
& LVO & 9 & $0.491-0.512$ & 0.5 & $0.382-0.394$ & 0.39 & $0.768-0.797$ & 0.779 \\
& RVO & 4 & $0.492-0.512$ & - & $0.373-0.385$ & - & $0.743-0.78$ & - \\
\hline
\end{tabular}


larger with the dorsal margin convex and the anterior margin regularly-rounded and more or less large $(C$. ophtalmica, C. exsculpta) (Sywula 1974, Petkovski 1976, Bronshtein 1988, Meisch 2000).

The sexual organs impressions are not always seen in the Cypria of the Turiec Basin. The bi-modal distribution of the length and height of the C. lenticulata n.sp. valves gives evidence of intra-specific variability (Fig. 3). The differences between the valves are particularly conspicuous on the postero-dorsal and posterior area where the sexual organs are located. We suppose the morphometric differences observed have their origin in sexual dimorphism. The males would be higher and angled on the postero-dorsal margin and the females more or less broadened.

The sexual dimorphism is also manifest in C. bodergatiae n.sp. but for the three other species described in this paper the differences between both sexes are not evident.

Heterochronous development (peramorphosis with acceleration) (McNamara 1986, Godfrey \& Sutherland
$1995)$ is noticed in some juveniles of $C$. isosceles n.sp. and $C$. polyphema n.sp. Indeed, their outline is similar to the adult specimens but their size is slightly smaller ; the other morphological characters - very narrow zone of fusion and lower calcification - are the juvenile ones. This anomaly is frequent in Slovenské Pravno field road locality which has provided 32 ostracod species (Candona, Euxinocythere, Herpetocypris, Darwinula, Candonopsis). In Cypria polyphema n.sp., the maximum height of abnormal individuals is on the left valve in front of mid - length. This character is only observed in the juvenile specimens. So, we could assume they belong to other species but it is only an hypothesis. It would be interesting to know the parameters which induce the variations of shape in ontogeny of species.

In the Turiec Basin, the minimum and maximum length range lies in the lower limit of the genus (Fig. 4). Among the Cypria species, C. bodergatiae n.sp. and $C$. lenticulata n.sp. are the shortest species known in Europe from the Miocene to the Recent. Their maximum length does not reach more than $0,55 \mathrm{~mm}$. The $C$.

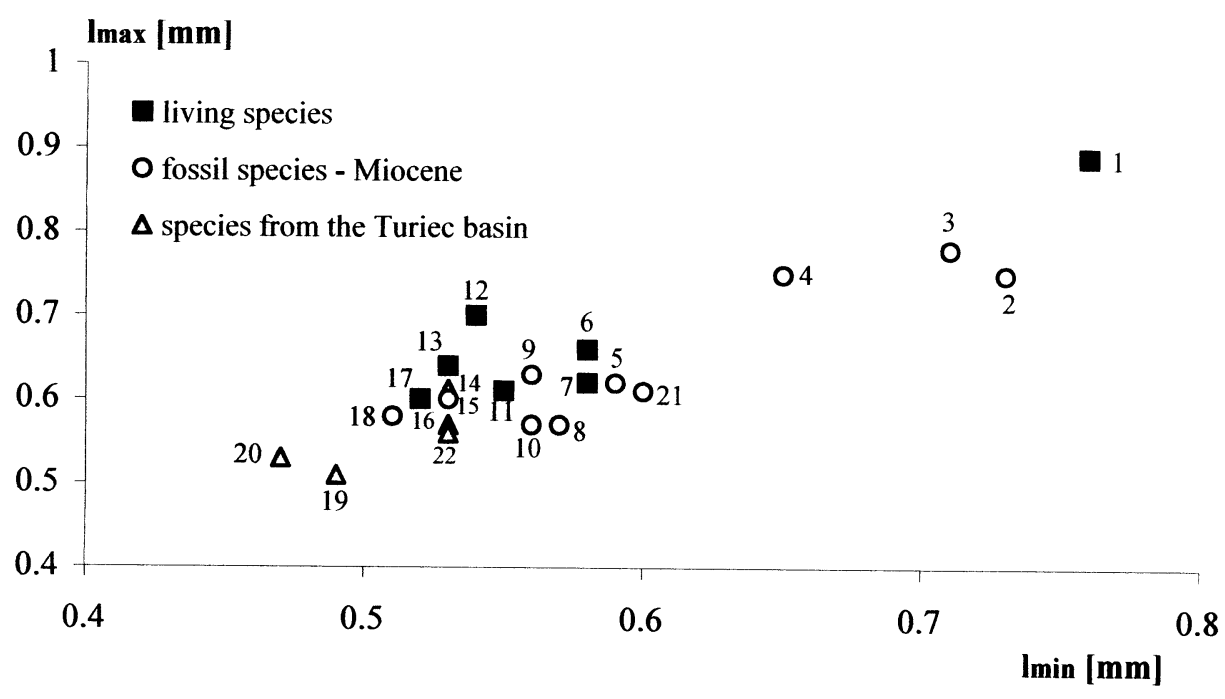

Fig. 4. Size of the Cypria species since Miocene as a minimum length $\left(1_{\min }\right)$ vs. maximum length $\left(1_{\max }\right)$. The species from the Turiec Basin are situated at the lower limit of the genus. 1. Cypria exsculpta (Fischer);2 . C. triebeli Krstić ; 3. C. dorsoconcava Krstić ; 4. C. reniformis (Hejjas) ; 5. C. pannonica Krstić ; 6. C. reptans Bronshtein ; 7. C. karamani Petkovski ; 8. C. siboviki Krstić ; 9. C. teslae Krstić ; 10. C. tocorjescui Hanganu ; 11. C. sywulae Meisch ; 12. C. ophtalmica (Jurine) ; 13. C. subsalsa Redeke ; 14. C. polyphema n.sp.; 15. C. abbreviata (Reuss) ; 16. C. isosceles n.sp. ; 17. C. sketi Petkovski ; 18. C. dorsalta Malz \& Moayedpour ; 19. C. bodergatiae n.sp. ; 20. C. lenticulata n.sp. ; 21. C. servica Krstić (from Belgrade area) ; 22. C. servica from the Turiec Basin (size of the species after Janz 1997, Jirícek 1985, Krstić 1975, Meisch 2000, Petkovski 1976, Reuss 1850). 


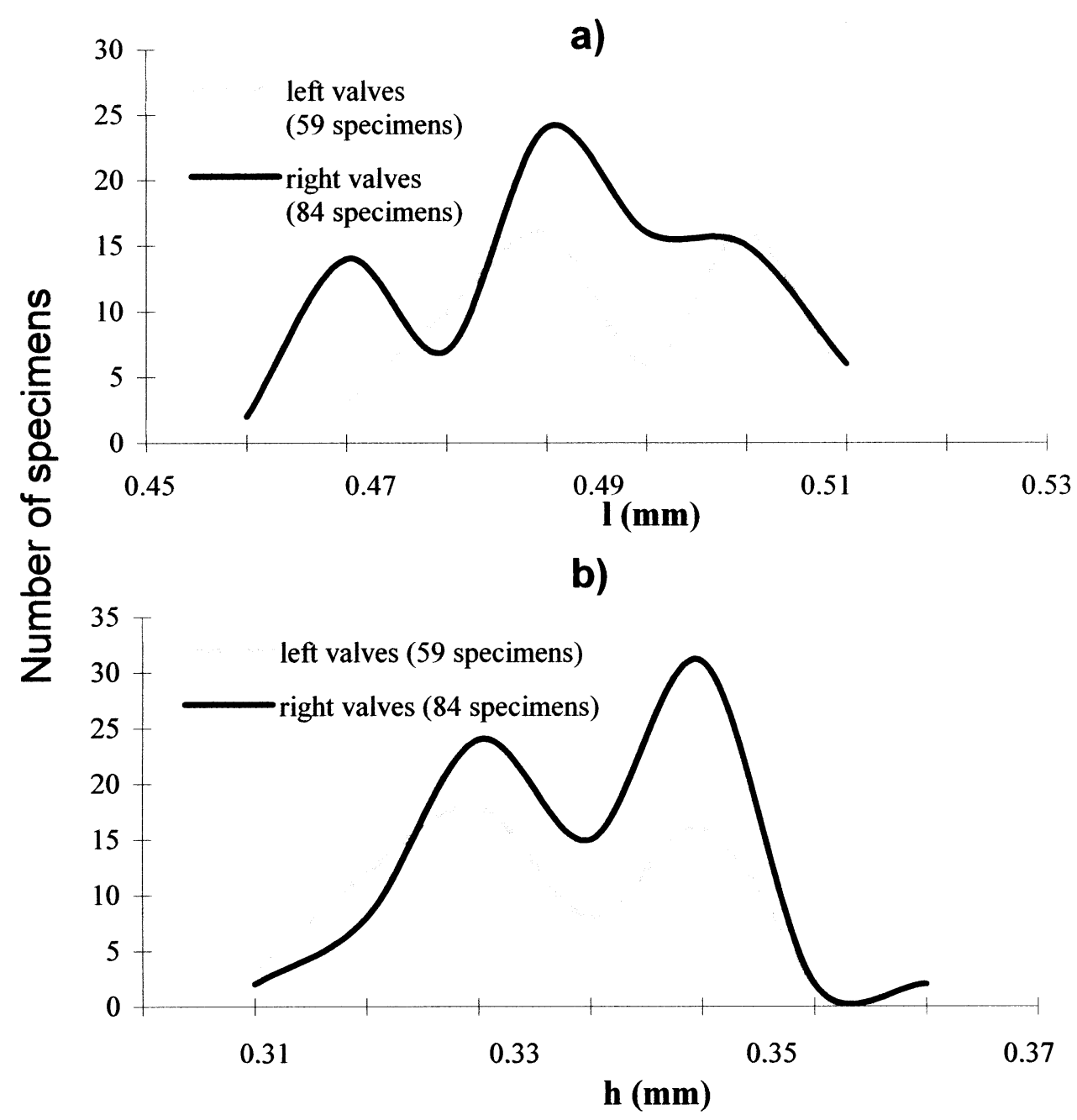

Fig. 3. Length (Fig. 3a) and height (Fig. 3b) distribution of the specimens of Cypria lenticula. A bidomal distribution of the valves results from the presence of sexual dimorphism. The males would be longer and higher than the females (see also Table 4).

servica Krstić individuals from Yugoslavia (Krstic 1975) are also larger than the Turiec ones. According to Martens (1994), the small size of species characterizes the endemic ones of the Ancient lakes.

The shape of the three new species of Cypria we have described in this paper is triangular, sub-triangular and sub-triangular to sub-elliptical. It is slightly different to the sub-circular one of C. polyphema n.sp. and C. lenticulata n.sp.
Cypria have been recorded in every area of the Turiec Basin (Fig.1). The three former species have been found in the Candona aculeata-armata-stagnosa-nubila-simplaria assemblage located in the central and southern area of the Turiec Basin. This assemblage includes trapezoidal, rectangular with sharp-pointed postero-ventral margin species and triangular Candona s.l. species. These shapes indicate small environmental fluctuations with a low temperature below 
$40 \mathrm{~m}$ in a profundal of the recent lakes (Dussart 1966, Carbonel et al. 1988). The triangular shapes of Cypria are also found in the Pannonian Basin (Central Paratethys) (Krstic 1975).

The sub-circular species (C. polyphema n.sp. and $C$. lenticulata n.sp.) have been found in the Cypria lenticulata and Herpetocypris denticulata assemblage and in Candona clivosa and C. robusta-jiriceki ones which occur in the northern part of the Turiec Basin and on its edge. The geological records which have provided these three assemblages are rich in recent species which occur in unstable environments (Herpetocypris Brady \& Norman 1889, Darwinula stevensoni (Brady \& Robertson 1870), Vestalenula pagliolii (Pinto \& Kotzian 1961), Heterocypris salina (Brady 1868), Pseudocandona compressa (Koch 1838), Fabaeformiscandona balatonica (Daday 1894)) and in vegetal remains which attest a shallow freshwater environment (Potamogeton, Nelumbium, Typha latissima, Characeae) (Sitár 1966, Pipík 2001). This environment corresponds to a littoral to sub-littoral area subdued great ecological variations (Pipík 2001).

We assume the environment could have influenced on the external outline of the Cypria valves. The triangular and sub-triangular outline could correspond to the stable environment. In the Cypria of the Turiec Basin, the differences at the level of the zone of the fusion have a specific value. On the other hand the external outline of the valve would not have any relationship with the intra-specific variation (except the sexual dimorphism). The variations noticed at the level of the outer margin of the Cypria valves would be connected with ecological fluctuations in the Turiec Basin and consequently express an adaptation to the life-environment. Similar observations have already been made on recent Candoninae species in Europe (Danielopol 1978).

\section{Acknowledgements}

This work was supported by the scientific co-operation between Slovakia and France. Financial support has been provided by the Foreign Office Ministry (France), the Comenius University of Bratislava, the Grant Agency for Science (project No. 1/0080/03) and UMR 5125, Paléoenvironnements and Paléobiosphère, University Claude Bernard, Lyon 1. Many thanks are due to Doctor John Neale (Hull, England) who has contributed usefully to the English language.

\section{References}

Absolon A. 1973. — Ostracoden aus einigen Profilen spät- und postglazialer Karbonatablagerungen in Mitteleuropa. Mitteilungen der Bayerischen Staatsamlung für Paleontologie und historische Geologie, 13, 47-94.

Bronshtein Z.S. 1988. - Freshwater ostracoda. Fauna of the USSR: Crustacean, vol. II, No.1. AA Balkema, Amsterdam, 455 p.
Carbonel P., Colin J.P., Danielopol D.I., Löffler H. \& Neustrueva I. 1988. - Paleoecology of limnic ostracodes: a review of some major topics. Palaeogeogr. Palaeoclim. Palaeoecol. special issue, Aspects of freshwater paleoecology and biogeography, Amsterdam 62, 1-4, 413-461.

Danielopol D.L. 1978. - Über Herkunft und Morphologie der Süßwasser-hypogäischen Candoninae (Crustacea, Ostracoda). Sitzungsberichte der Österreichische Akademie der Wissenschaften, mathematisch-naturwissenschaftliche Klasse, Abteilung I, 187, 1-162.

Devoto G. 1965. - Lacustrine Pleistocene in the lower Liri valley. Geologica Romana, IV, 291-368.

Diebel K. \& Pietrzeniuk E. 1975. — Mittel- und jungpleistozäne Ostracodenfaunen des Raums Potsdam - Brandenburg - Rathenow in stratigraphischer und ökologischer Sicht. Zeitschrift für geologische Wissenschaften 3, 9, 1197-1233.

Diebel K. \& Pietrzeniuk E. 1977. — Ostracoden aus dem Travertin von Taubach bei Weimar. Quartärpaläontologie, 2, 119-137.

Diebel K. \& Pietrzeniuk E. 1978. — Die Ostrakodenfauna des eeminterglazialen Travertins von Burgtonna in Thüringen. Quartärpaläontologie, 3, 87-91.

Diebel K. \& Pietrzeniuk E. 1984. — Jungpleistozäne Ostrakoden aus Sedimenten der Parkhöhlen von Weimar. Quartärpaläontologie, 5, 285-319.

Dussart B. 1966. - Limnologie, l'étude des eaux continentales. Gauthier-Villars, Paris, 677 p.

Fuhrmann R. \& Pietrzeniuk E. 1990. - Die Ostrakodenfauna des Interglazials von Gröbern (Kreis Gräfenhainichen). Altenberger naturwissenschaftliche Forschungen, Altenburg, 5, 202-227.

Godfrey L.R. \& Sutherland M.R. 1995. — What's growth got to do with it? Process and product in the evolution of ontogeny. J. Human Evol., 29, 405-431.

Janz H. 1997. — Die Ostrakoden der kleini-Schichten des miozänen Kratersees von Steinheim am Albuch (Süddeutschland). Stuttgarter Beiträge zur Naturkunde, B (Geologie und Paläontologie), 251, 1-101.

Jiřicek R. 1985. — Die Ostracoden des Pannonien. Pages 378-408 in Chronostratigraphie und Neostratotypen, Miozän der Zentral Paratethys, Bd. VII, $M_{6}$ Pannonien (Slavonien und Serbien). Papp A. (ed.), Akadémiai Kiado, Budapest.

Kantorek J. \& Absolon A. 1975. - Cypria helokrenica sp. n., eine neue Ostracoden-Art der Quellfauna. Veštnik cěskoslovenské společnosti zoologické, Praha, XXXIX, 3, 211-217.

Krstić N. 1972. - Rod Candona (Ostracoda) iz kongerijskikh slojeva juzhnog dela Panonskog basena (Genus Candona (Ostracoda) from Congeria beds of Southern Pannonian Basin). The Serbian Academy of Sciences and Arts, Monographs, CDL, 39: 145 p. (in Serbian with English summary)

Krstić N. 1975. - Ostrakodi Kongerijskih slojeva: 7. Vrstve roda Cypria i neke druge nedovoljno definisane forme. (Ostracode of the Congerian beds, 7, Specia of the genus Cypria and some other insufficiently defined forms). Institute for Geological and Mining Exploration and Investigation of Nuclear and other Mineral Raw Materials, Belgrade, 10, 195-205. (in Serbian with English summary)

Malz H. \& Moayedpour E. 1973. — Miozäne Süflwasser-Ostracoden aus der Rhön. Senckenbergiana lethaea 54, 2/4, 281-309.

Mandelstam M.I. \& Schneider G.F. 1963. — Iskopaemye ostrakody SSSR, semeistvo Cyprididae. (The fossile ostracods of the USSR, family Cyprididae). Trudy VNIGRI, 203, 1-242. (in Russian)

Martens K. 1994. - Ostracod speciation in ancient lakes: a review. Pages 203-222 in: Speciation in ancient lakes. Martens K., Goddeeris B. \& Coulter G. (eds.). Archiv für Hydrobiologie Beih. Ergebnisse der Limnologie, 44, Stuttgart. 
McNamara K.J. 1986. - A guide to the nomenclature of Heterochrony. J. Paleontol., 6, 1, 4-13.

Meisch C. 2000. - Freshwater Ostracoda of Western and Central Europe. Spektrum Akademischer Verlag, Heidelberg - Berlin, $522 \mathrm{p}$.

Morkhoven F.P.C.M. van 1962. - Post-paleozoic Ostracoda, Their Morphology, Taxonomy, and Economic Use. I (1962), II (1963). Elsevier Publishing Company, Amsterdam-London-New York, $478 \mathrm{p}$.

Petkovski T.K. 1976. - Zwei neue und eine seltene Ostracoden-Art der Gattung Cypria Zenker aus Jugoslawien. Acta Musei Macedonici Scientiarum Naturalium XIV, 7, 173-192.

Pietrzeniuk E. 1991. — Die Ostrakodenfauna des Eem Intergalzials von Schönfeld, Kr. Calau (Niederlausitz). Natur und Landschaft in der Niederlausitz, Sonderheft, 92-116.

Pipík R. 1996. — Paleoekológia ostrakód z Borského Sv. Jura a Pezinka (Paleoecology of the ostracods from Borský Sv. Jur and Pezinok). Diploma work, Faculty of Sciences, Comenius University, Bratislava. 75 p. (in Slovak)

Pipík R. 2000. - Neogene habitats and freshwater Ostracoda on the territory of Slovakia. Slovak Geological Magazine 6, 2-3, 116 119.

Pipík R. 2001. - Les Ostracodes d'un lac ancien et ses paléobiotopes au Miocène supérieur: le Bassin de Turiec (Slovaquie). $\mathrm{PhD}$ Thesis, Université Claude-Bernard, Lyon I. 337 p.

Pipík R. \& Bodergat A.M. - Le genre Euxinocythere (Ostracoda, Cytheridae, Leptocytherinae) dans le Miocène supérieur du Bassin de Turiec (Slovaquie) : taxonomie et paléoécologie. Rev. Micropaléontol., in press.

Reuss A.E. 1850. — Die fossilen Entomostraceen des österreichischen Tertiärbeckens. Wilhelm Haidinger's Naturwissenschaftliche Abhandlungen, Wien, III, 41-92.
Rühle E. 1994. - Geology of Poland. Atlas of Guide and Characteristic fossils, Warsaw, III (3b),75-90.

Rybecký M. 1986. — Lastúrnicky (Ostracoda) pramenov a stojatých vôd z územia Slovenska a stúdium ekológie významnejsích druhov (The ostracods (Ostracoda) of springs and stagnant waters of the territory of Slovakia and a study of ecology of the most significant species). PhD Thesis, Faculty of Sciences, Comenius University, Bratislava. 131 p. (in Slovak)

Sitár V. 1966. - Paleoflóra Turčianskej kotliny a jej vzt'ahy k stredoeurópskym flóram (Paleoflore of the Turiec Basin and its relations to Central European flora). Manuscript, Geofond Bratislava, 123 p. (in Slovak)

Sokac A. 1972. - Pannonian and Pontian ostracode fauna of Mt. Medvednica. Palaeontologica Jugoslavica, 11, 1-140.

Sokac A. 1978. - Pleistocene ostracode fauna of the Pannonian basin in Croatia. Palaeontologica Jugoslavica, 20, 1-51.

Staplin F.L. 1963. - Pleistocene Ostracoda of Illinois, Part II. Subfamilies Cyclocyprinae, Cypridopsinae, Ilyocyprinae ; Families Darwinulidae and Cytheridae. Stratigraphic ranges and assemblages patterns. J. Paleontol., 37, 1164-1203.

Sywula T. 1974. - Malzoracki (Ostracoda) - Fauna slodkovodna Polski (The Ostracods (Ostracoda) - Freshwater fauna of Poland). Panstwowe wydawnictvo naukowe, Warszawa - Poznan, 24, 315 p. (in Polish).

Tetart J. 1975. - Recherches sur la reproduction et l'écologie de quelques Ostracodes (Cyprididae). PhD Thesis, Grenoble, $217 \mathrm{p}$.

Witt W. 2000. — Süflwasserostracoden der miozänen Vorlandmolasse Süddeutschland. Mitteilungen der Bayerischen Staatssam lungen für Palôaontologie und historische Geologie, 40, 109-151. 